\section{Lepidodactylus lugubris (Mourning Gecko).} Distribution.

Dates of observation: 24 December 2011 and 13 May 2013, respectively. Locations: Guadeloupe, Grande Terre, Pointeà-Pitre, Chanzy (16.242286, -61.537800, 8m), and Le Gosier, Pointe de la Verdure (16.205556, -61.499222, 12m). Voucher: image by $B$. Ibéné. Following the observations made in 2010 and 2011 in the municipality of Les Abymes (O. Lorvelec, A. Levesque and A. M. Bauer, 2011, Herpetology Notes, 4: 291294), we made two additional observations in two new municipalities. These indicate that this species is established in Guadeloupe, on the island of Grande Terre. The first observation concerns a specimen found dead in a gymnasium at Pointe-à-Pitre. It was captured, preserved in alcohol, and deposited at the Muséum national d'Histoire naturelle of Paris by O. Lorvelec. Voucher: Image by R. Gomès. The second observation concerns two specimens observed on the walls of a house on the coast of Pointe de la Verdure, Le Gosier. These specimens were photographed, captured and filmed.
Régis Gomès, ASFA, regis.gomes@hotmail.fr and Béatrice Ibéné, ASFA, beatrice.ibene@wanadoo.fr, L'Association pour la Sauvegarde et la réhabilitation de la Faune des Antilles: Morne Burat 971780 SAINTE-ANNE Guadeloupe-FWI.

Citation: Gomès R., Ibéné B. 2013. Lepidodactylus lugubris (Mourning Gecko). Distribution. Caribbean Herpetology 44:1.

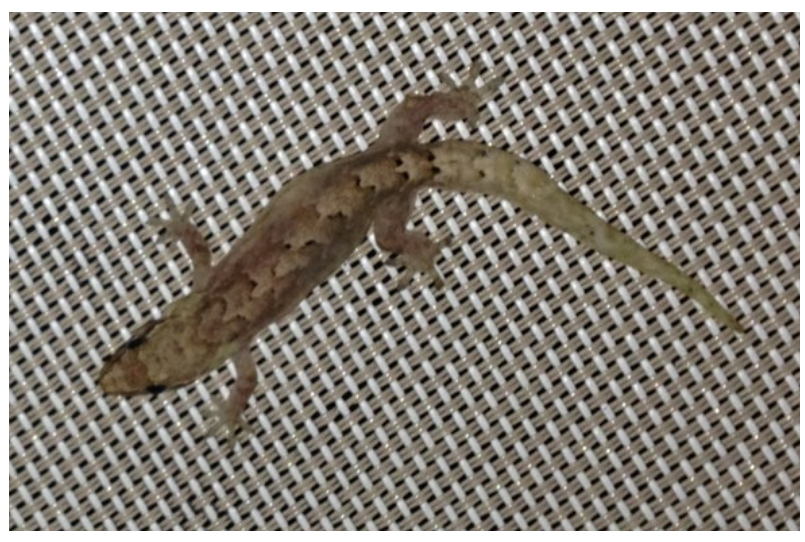

Published online 27 September 2013 